\title{
CAUSAL ATTRIBUTION TO CERVICAL CANCER
}

\section{CAUSAL ATTRIBUTION TO CERVICAL CANCER}

\author{
Ana Carolina Peuker, María Julia Armiliato, Luísa Vital de Souza \& Elisa Kern de Castro \\ Health Sciences Center, Universidade do Rio do Vale dos Sinos (UNISINOS), Brazil
}

\begin{abstract}
This study aimed to examine the causal attribution for cervical cancer for women with and without the disease. Seventy-eight (78) users from the public healthcare system participated, which were divided into: a clinical group (CG) of women with cervical cancer and a non-clinical group (NCG) of women without cervical cancer. A Form covering sociodemographic and clinical data was utilized along with the Portuguese version of the Illness Perception Questionnaire for ill patients and healthy people. The responses were grouped into six categories: 1 ) Psychological attributions; 2) Behavioral risk factors; 3) Biological factors; 4) Bad luck; 5) Lack of resources; 6) Chemical agents. The CG attributed more emotional causes to the Cervical Cancer while the NCG more causes associated with behavioral risk factors. These results suggest that women with cancer may blame themselves for the illness. Distorted beliefs about the etiology of cervical cancer can harm preventative conduct and self-care practices.
\end{abstract}

Keywords: Self-regulation; cancer; causation; women's health.

\section{Resumen}

El estudio buscó examinar la atribución de causas del cáncer cervical de mujeres con y sin la enfermedad. Participaron setenta y ocho (78) usuarias del sistema público de salud, que fueron divididas en: grupo clínico (GC) de mujeres con cáncer cervical, y grupo no-clínico (GNC) de mujeres sin cáncer cervical. Fue utilizado un cuestionario de datos sociodemográficos y clínicos y la versión en portugués del IIIness Perception Questionnaire para pacientes enfermos y personas sanas. Las respuestas fueron agrupadas en seis categorías: 1) Atribuciones psicológicas; 2) Factores de riscos comportamentales; 3) Factores biológicos; 4) Mala suerte; 5) Falta de recursos; 6) Agentes químicos. El GC atribuyó más causas emocionales al cáncer cervical, mientras el GNC atribuyó más causas asociadas a factores de risco comportamentales. Los resultados sugieren que mujeres con cáncer pueden culparse a sí mismas por la enfermedad. Creencias equivocadas sobre la etiología del cáncer cervical pueden perjudicar conductas de prevención y prácticas de autocuidado.

Palabras clave: Auto-regulación; cáncer; causas; salud de la mujer.

\section{INTRODUCTION}

Cervical cancer (CC) is the third most frequent cancer in women worldwide ${ }^{(1)}$ and in Brazil, it is in second place among the cancers that affect the most women ${ }^{(2)}$. This type of cancer has a good prognosis when diagnosed early, but there is still a high

\section{Correspondencia:}

Elisa Kern de Castro

Health Sciences Center, Universidade do Rio do Vale dos Sinos (UNISINOS)

Avenida Unisinos 950, Bairro Cristo Rei, São Leopoldo, RS, Brazil, CEP 93022-000. Tel: +55 5135911122

E-mail: elisakc@unisinos.br 
mortality rate for this disease in $\mathrm{Brazi}^{(3)}$. Its evolution is slow, starting out as a lesion in the cervix ${ }^{(2-4)}$, and can take anywhere from eight to ten years to be diagnosed.

The precursor lesion of CC is asymptomatic. Symptoms appear when the disease is in advanced stages (intermittent vaginal bleeding or following intercourse, abnormal vaginal discharge and abdominal pain associated with urinary or intestinal complaints). Among the risk factors for the development of $\mathrm{CC}$, the most common is being infected with the human papillomavirus (HPV), low immunity, age (peak incidence between 50 and 60 years), early onset of sexual life, multiple sexual partners, smoking, prolonged use of oral contraceptives and lack of prevention, such as not taking the Papanicolaou test ${ }^{(2-5)}$.

In addition to physical symptoms, psychological and emotional changes can occur in women with cancer, such as anxiety, fear of death, doubts arising from the misinformation regarding the clinical picture, insecurity and experiencing an impact on sexuality ${ }^{(6)}$. When a person is affected by a disease, one of the first questions she asks is "why?" Which is an attempt to self-regulate her behavior and emotions in an effort to adjust to the new reality. Spontaneously, individuals seek explanations and try to integrate them, in a consistent and predictable way, into their outlook on the world. This tendency becomes more prominent as the severity of the event worsens. Causal attribution is one of the central components of the representation of the disease. The perception that the individual has about the causes of a disease is one of the key elements described in the literature for understanding the perception that patient has about the disease, together with the identity (symptoms), consequences, personal and treatment control, coherence and emotional representation ${ }^{(7-8)}$.

Specifically with regard to the causes of a disease, the process in which people seek explanations about a particular health condition can be classified into three dimensions: locus, stability and controllability ${ }^{(9)}$. The locus dimension reflects whether the cause is inside (internal) or outside (external) to the person. The stability dimension refers to how the cause changes over time (stable or unstable), while the controllability is related to the degree in which the cause depends on the will of the person (volitional; modifiable) or not (unchanging). Therefore, the causal attributions related to lifestyle, such as physical inactivity can be understood as being internal to the individual and modifiable. On the other hand, causal attributions of cancer linked to environmental factors such as air pollution, can be considered external to the person and not modifiable, but permanent instead ${ }^{(10)}$.

The beliefs about a disease are not always congruent with the consensus of experts in the field. In the case of breast cancer, for example, an extensive systematic review of the literature was produced over a period of 30 years (1982-2012) on the causal attributions of the disease, which showed that women who have had breast cancer, unlike the consensus among professional healthcare specialists, did not attribute to the etiology of cancer factors such as age, physical inactivity, breast density, alcohol consumption and reproductive history. In general, the women affected tend to associate the causes of cancer to factors out of their control and external to their will, even if the scientific evidence demonstrates the importance of lifestyle behaviors that are modifiable in terms of the control and reduction of the risk for the disease ${ }^{(10)}$.

The understanding of the causes of the disease may influence the thoughts and actions surrounding this very topic, as well as self-care behaviors ${ }^{(11)}$. For example, women who hold the belief that Cervical Cancer is a harmless disease, due to the absence of 
symptoms in the beginning, can develop a passive and negligent attitude toward selfcare, thus avoiding screening tests or the routine medical consultation ${ }^{(12)}$.

The analysis of causal attributions, in an isolated manner, can not explain the complexity of human behavior, nor predict a person's actions. However, knowing the beliefs held by women about the origin of the cancer makes it possible to verify the influence of such cognitions on the decision to seek medical assistance, on the adherence with the therapeutic plan and on the psychological adjustment during and after treatment ${ }^{(8)}$. In addition, understanding how women attribute causes to cancer is relevant for health promotion, including a greater awareness and dissemination of early detection programs, treatment and development of public policies. It is known that the causal attributions can affect the response of women to messages in relation to health and the adoption of behaviors related to prevention, including screening tests ${ }^{(13)}$.

Given the above, the aim of this study was to examine and compare the causal attribution of CC in two groups of women: those with Cervical Cancer and those without Cervical Cancer. In addition, a system of classification of the causal attribution to Cervical Cancer was proposed, as provided by the women from these two groups.

\section{METHOD}

This is a cross-sectional study involving the comparison of groups (case-control).

\section{Participants}

The sample consisted of 78 adult women (between 18 and 65 years of age), comprising the two groups. The clinical group (CG) consisted of women diagnosed with CC ( $N=39)$, having a mean age of 45.68 years $(S D=10.47)$. The nonclinical group (NCG) consisted of women without $C C(N=39)$, having a mean age of 44.56 years $(\mathrm{SD}=9.6)$. Women were recruited in a public hospital and in a Primary Healthcare Unit of Porto Alegre/RS. Women with other diseases related to the reproductive system and pregnant women were excluded.

\section{Instruments}

a) Form covering sociodemographic and clinical data: an instrument developed by the research group, which was used to describe the sample. It contained questions relating to marital status, education, work and information regarding the treatment of the Cervical Cancer, if the participant was diagnosed with CC.

b) Causes of the disease component from the Revised IIIness Perception Questionnaire (IPQ-R): translated into Portuguese (Portugal) by Figueiras, Machado and Alves) ${ }^{(14)}$. This was used in order to assess the representations of the disease according to the theoretical model of self-regulation of health behavior proposed by Leventhal et al. (7;15). It is an instrument consisting of nine subscales (identity, cyclical timeline, acute/chronic timeline, consequences, personal control, treatment control, coherence, causes and emotional representation). This study only analyzed the part of the instrument relating to the investigation of the causes of the cancer, as spontaneously attributed by the women. Thus, we asked the participants to respond spontaneously while identifying the three main causes of the emergence of the CC, starting with the most prominent.

c) Causes of the disease component from the Revised Illness Perception Questionnaire for Healthy People (IPQ-RH): 
developed by Figueiras and Alves ${ }^{(16)}$ based on the Revised IIIness Perception Questionnaire (IPQ-R) ${ }^{(17)}$ evaluates the perception of the disease in healthy subjects. The instrument is organized according to the three sections of the IPQ-R. In the same manner as the IPQ- $R$, this study only utilized the description of the causes spontaneously given by the women regarding Cervical Cancer.

d) Form categorizing the causes attributed to the cancer: instrument developed by the authors to assist the judges in the categorization of the women's responses. This instrument contains a list of categories in which the judges should classify the literal responses made by the women.

\section{Ethical procedures}

The research was approved by the Research Ethics Committee, under the Official Opinion number 337b / 10. All participants signed the Informed Consent Form (ICF) in order to participate in the study, and all the necessary ethical recommendations, inherent in a project developed with humans were followed.

\section{Data collection procedures}

The patients were invited to participate after verifying their medical records at the hospital and the certification of their diagnosis by the doctor. They were approached in the waiting room while awaiting their doctor's appointment and were taken to a consultation room in the same hospital, where the instruments were applied. The women in the clinical group were awaiting their consultation in the hospital's oncology sector, while the women in the non-clinical group were in the waiting room of the Gynecology sector at the same hospital.

Due to the difficulties that some participants had with reading and interpreting the text due to the lack of schooling, we decided to standardize the application of the instruments. Whereby, the interviewers read the questions from the questionnaires to all the participants, who answered the questions orally. The interviews were applied individually, in a private room, thus maintaining the privacy of patients.

\section{Data analysis}

Step 1: The categorization was based on a review of the literature in the area ${ }^{(18)}$. After the exhaustive reading of the responses provided by the participants, groups were generated considering the respective semantic content. Four categories were created (Psychological Attribution; Biological risk factor, Behavioral risk factor; Others) and 16 subcategories, which underwent the concordance analysis of the judges (psycho-oncology experts). Upon considering the analysis of the judges, it was found that the designated categories were insufficient. Thus, the Others category was divided into three new categories: Bad luck; Lack of resources and Chemical agents. In addition, two subcategories were excluded and three were created. In the end, the total was six categories and 14 subcategories, as presented in table.

Step 2: Classification of the responses by the judges

In order to verify the validity of each category, two judges (psychologists with clinical and research experience) were asked to classify, independently, the causes attributed to cancer by the women. By using a categorization form, each judge assigned a number for each subcategory ( 1 to 14) for each of the responses provided by the participants. After the categorization of the responses by the judges, the concordance was analyzed by way of the Kappa Coefficient. The ratio obtained was 0.836 


\section{Table 1. Categories, subcategories and examples of the causes attributed to Cervical Cancer by the women}

\begin{tabular}{|c|c|c|}
\hline Categories & Subcategories & Examples \\
\hline \multirow{3}{*}{$\begin{array}{l}\text { 1) Psychological } \\
\text { Attribution }\end{array}$} & $\begin{array}{l}\text { Psychological and / or psychiatric } \\
\text { symptoms }\end{array}$ & Emotional state, stress, worry, hurt, grief \\
\hline & Stressful events & Family problems, work related stress \\
\hline & Personality & Negative thinking, the person's "way of being" \\
\hline \multirow{6}{*}{$\begin{array}{l}\text { 2) Biological Risk } \\
\text { Factor }\end{array}$} & Genetic/Hereditary & Heredity, genetics \\
\hline & Poor organ function & Changes in the body's defenses, low immunity \\
\hline & Hormonal causes & Hormonal, contraceptive use \\
\hline & Virus or lesion by HPV & HPV Infection \\
\hline & Microbiological agents (not HPV) & Microbes, bacteria \\
\hline & Other lesions & Wound, bruise, accident \\
\hline \multirow{5}{*}{$\begin{array}{l}\text { 3) Behavioral Risk } \\
\text { Factor }\end{array}$} & Drug use & Smoking, alcohol use \\
\hline & Risky sexual behavior & $\begin{array}{l}\text { STDs, sexual intercourse without condoms, } \\
\text { multiple sexual partners }\end{array}$ \\
\hline & Lack of prevention & $\begin{array}{l}\text { Poor diet, lack of prevention, physical inactivity, } \\
\text { carelessness }\end{array}$ \\
\hline & Hygiene & $\begin{array}{l}\text { Lack of personal hygiene, contact with } \\
\text { contaminated site }\end{array}$ \\
\hline & Nonspecific behaviors & Behavioral habits, lifestyle \\
\hline 4) Bad luck & & Destiny, fate \\
\hline 5) Lack of resources & & $\begin{array}{l}\text { Little medical care, lack of information, delays } \\
\text { in medical care }\end{array}$ \\
\hline 6) Chemical agents & & Pollution, pesticides \\
\hline
\end{tabular}

for the first spontaneous response (Cause $1), 0.881$ for the second response (Cause 2) and 0.886 for the third response (Cause 3), which implied a high-degree of concordance among the judges.

\section{RESULTS}

In relation to sociodemographic characteristics, in the CG $56.4 \%(\mathrm{~F}=22)$ were married, 28.2\% ( $F=11)$ single, 10.3\% ( $F$ $=4)$ separated and $5.1 \%(F=2)$ were widows. Regarding the level of education, $56.4 \%(F=22)$ had completed elementary school, 25.6\% ( F = 10) completed high school, $15.4 \%(F=6)$ had a university degree and $2.6 \%(F=1)$ had no schooling. In addition, 53.8\% $(\mathrm{F}=21)$ did not work.
In regards to the clinical characteristics, $30.8 \%$ underwent chemotherapy, $43.6 \%$ radiotherapy, $25.6 \%$ brachytherapy, $5.1 \%$ hormone therapy and $53.8 \%$ surgery.

In the $\mathrm{NCG}, 38.5 \%(\mathrm{~F}=5)$ were married, $30.8 \%(F=12)$ were single, $23.1 \%$ ( $F$ $=9)$ were separated and $7.7 \%(F=3)$ were widows. Regarding the level of education, $56.4 \%(F=22)$ had completed elementary school, 25.6\% ( F = 10) completed high school, $15.4 \%(F=6)$ had a university degree and $2.6 \%(F=1)$ had no schooling. In addition, 35.9\% $(F=14)$ did not work.

Regarding the causes attributed to Cervical Cancer by the CG, it was found that in the first spontaneous response regarding the cause of the disease, labeled as Cause 1 , the most frequent category was 
Psychological Attribution (35.9\%; $F=14$ ), followed by Biological Risk Factor $(20.5 \%$; $\mathrm{F}=8$ ), Behavioral Risk Factor (15.4\%; $\mathrm{F}=$ 6), Bad Luck $(10.3 \% ; F=4)$, Lack of Resources $(10,3 \% ; F=4)$ and Do Not Know $(7.7 \% ; F=3)$. In Cause 2, the category most frequently reported by the CG was Do Not Know $(28.2 \%$; $F=11)$, followed by Psychological Attribution (20.5\%; F = 8), Biological Risk Factor $(20.5 \% ; F=8)$ and the Behavioral Risk Factor $(15.4 \%$; $\mathrm{F}=$ 6). In Cause 3, the category most reported by the CG was Do Not Know $(41 \%$; F = 16), followed by Psychological Attribution $(30.8 \% ; F=12)$, Biological Risk Factor $(12.8 \% ; F=5)$, Behavioral Risk Factor $(12.8 \% ; F=5)$ and then Chemical agents $(2.6 \% ; \mathrm{F}=1)$.

In regards to the NCG, the causes attributed to Cervical Cancer in Cause 1 were the Behavioral Risk Factor $(71.8 \%$; $\mathrm{F}=$ 28), followed by the Biological Risk Factor $(10.3 \% ; F=4)$, Lack of Resources $(7.7 \%$; $\mathrm{F}=3$ ), Psychological Attribution $(7.7 \%$; $\mathrm{F}$ $=3)$ and lastly Do Not Know $(2.6 \%$; F = $1)$. In Cause 2 , the most frequently mentioned category was the Behavioral Risk Factor $(46.2 \% ; F=18)$, followed by Do Not Know $(23.1 \%$; $F=9$ ), Biological Risk Factor $(17.9 \%$ and $F=7)$ and lastly Psychological Attribution (12.8\%; F = 5). In Cause 3, the category most reported by the NCG was Do Not Know $(41 \%$; $F=$ 16), followed by the Biological Risk Factor $(25.6 \% ; F=10)$, Behavioral Risk Factor $(23.1 \% ; F=9)$, Psychological Attribution $(5.1 \% ; \mathrm{F}=2)$ Lack of Resources $(2.6 \% ; \mathrm{F}=$ 1 ) and Chemical agents $(2.6 \% ; F=1)$. Answers falling within the category Bad Luck and Hormonal Causes were not mentioned by the participants of the group of women without cervical cancer.

Possible differences were tested in the causes attributed by the CG and by the NCG by using the $X^{2}$ test. In this analysis, the "Do not know" responses were excluded in order to show the differences bet- ween the groups with more accuracy. The results revealed that there were differences between the groups in relation to Cause 1 $\left(X^{2}=26.76 ; \mathrm{p}<0.005 ; \mathrm{df}=4\right)$; in Cause 2 $\left(\mathrm{X}^{2}=12.705, \mathrm{p}<0.005 ; \mathrm{df}=3\right)$ and Cause $\underline{3}\left(X^{2}=10.952, p<0.05 ; d f=4\right)$. It was observed that, in general, the women of the CG attributed causes that were more related to the emotional and psychological aspects, while the NCG associated the causes of cancer to behavioral risk factors, as shown in table 2 .

\section{DISCUSSION}

This study investigated the causal attribution to Cervical Cancer for women with and without the disease. In addition, we elaborated a system of classification of the responses provided by the women about the causes of CC, which was evaluated by independent judges. The results showed that the control group, associated the issues of an emotional nature (grief, worry, sadness, hurt, stress, etc.) with the etiology of cervical cancer more than the women of the NCG did. Negative emotions such as anger, sadness and guilt can intensify to the extent that the factors perceived by the women as being causes of the disease, are difficult to be modified (eg. family problems, betrayal, loss of loved ones, disagreements in the past), demonstrating an internal locus of causality, that can not be changed or can only undergo slight changes, while being difficult to control ${ }^{(9)}$. A woman with CC may feel helpless, while being faced with a negative scenario that combines the reality of having the disease with the guilt of having been the victim of situations that, from her perspective, may have caused the illness in the first place ${ }^{(6)}$. That is, in addition to the existing concerns about the disease and treatment, the causal attribution of beliefs about the disease can bring about even more sorrow, creating a vicious circle. 


\section{Table 2. Causal attribution of Cervical Cancer of the CG and NCG groups}

\begin{tabular}{|c|c|c|c|c|c|c|c|c|c|c|c|c|c|c|c|}
\hline \multirow[b]{3}{*}{ Categorias } & \multicolumn{4}{|c|}{ Cause 1} & \multirow[b]{3}{*}{$x^{2}$} & \multicolumn{4}{|c|}{ Cause 2} & & \multicolumn{4}{|c|}{ Cause 3} & \\
\hline & \multicolumn{2}{|c|}{$\begin{array}{c}\text { GC } \\
(\mathrm{n}=39)\end{array}$} & \multicolumn{2}{|c|}{$\begin{array}{c}\text { GNC } \\
(n=39)\end{array}$} & & \multicolumn{2}{|c|}{$\begin{array}{c}\mathrm{GC} \\
(\mathrm{n}=39)\end{array}$} & \multicolumn{2}{|c|}{$\begin{array}{c}\mathrm{GNC} \\
(\mathrm{n}=39)\end{array}$} & \multirow[b]{2}{*}{$x^{2}$} & \multicolumn{2}{|c|}{$\begin{array}{c}\text { GC } \\
(\mathrm{n}=39)\end{array}$} & \multicolumn{2}{|c|}{$\begin{array}{c}\text { GNC } \\
(n=39)\end{array}$} & \multirow[b]{2}{*}{$x^{2}$} \\
\hline & $\%$ & $\mathrm{~F}$ & $\%$ & $\mathrm{~F}$ & & $\%$ & $\mathrm{~F}$ & $\%$ & $\mathrm{~F}$ & & $\%$ & $\mathrm{~F}$ & $\%$ & $\mathrm{~F}$ & \\
\hline Psychological Attribution & 33.4 & 13 & 7.7 & 3 & & 20.5 & 8 & 15.5 & 6 & & 30.8 & 12 & 5.2 & 2 & \\
\hline $\begin{array}{l}\text { Psychological and / or } \\
\text { psychiatric symptoms }\end{array}$ & 23.1 & 9 & 7.7 & 3 & & 12.8 & 5 & 10.3 & 4 & & 15.4 & 6 & 2.6 & 1 & \\
\hline Stressful events & 10.3 & 4 & 0 & 0 & & 7.7 & 3 & 5.2 & 2 & & 7.7 & 3 & 0 & 0 & \\
\hline Personality & 0 & 0 & 0 & 0 & & 0 & 0 & 0 & 0 & & 7.7 & 3 & 2.6 & 1 & \\
\hline Biological Risk Factor & 20.6 & 8 & 10.3 & 4 & & 20.5 & 8 & 18 & 7 & & 12.9 & 5 & 25.6 & 10 & \\
\hline Genetic/Hereditary & 10.3 & 4 & 5.1 & 2 & & 7.7 & 3 & 12.8 & 5 & & 2.6 & 1 & 2.6 & 1 & \\
\hline Poor organ function & 0 & 0 & 2.6 & 1 & & 7.7 & 3 & 0 & 0 & & 7.7 & 3 & 7.7 & 3 & \\
\hline Hormonal causes & 0 & 0 & 0 & 0 & & 0 & 0 & 0 & 0 & & 2.6 & 1 & 0 & 0 & \\
\hline Virus or lesion by HPV & 10.3 & 4 & 0 & 0 & & 5.1 & 2 & 2.6 & 1 & & 0 & 0 & 7.7 & 3 & \\
\hline $\begin{array}{l}\text { Microbiological agents } \\
\text { (not HPV) }\end{array}$ & 0 & 0 & 0 & 0 & & 0 & 0 & 0 & 0 & & 0 & 0 & 7.7 & 3 & \\
\hline Other lesions & 0 & 0 & 2.6 & 1 & $26.795^{*}$ & 0 & 0 & 2.6 & 1 & $12.705^{*}$ & 0 & 0 & 0 & 0 & $10,952^{* *}$ \\
\hline Behavioral Risk Factor & 15.4 & 6 & 73.1 & 29 & & 18 & 7 & 43.6 & 17 & & 12.9 & 5 & 23.1 & 9 & \\
\hline Drug use & 10.3 & 4 & 2.6 & 1 & & 2.6 & 1 & 0 & 0 & & 0 & 0 & 2.6 & 1 & \\
\hline Risky sexual behavior & 5.1 & 2 & 17.6 & 7 & & 0 & 0 & 17.9 & 7 & & 2.6 & 1 & 2.6 & 1 & \\
\hline Lack of prevention & 0 & 0 & 51.3 & 20 & & 12.8 & 5 & 20.5 & 8 & & 10.3 & 4 & 17.9 & 7 & \\
\hline Hygiene & 0 & 0 & 2.6 & 1 & & 2.6 & 1 & 2.6 & 1 & & 0 & 0 & 0 & 0 & \\
\hline Nonspecific behaviors & 0 & 0 & 0 & 0 & & 0 & 0 & 2.6 & 1 & & 0 & 0 & 0 & 0 & \\
\hline Bad luck & 12.8 & 5 & $\mathbf{0}$ & 0 & & 0 & 0 & 0 & 0 & & 0 & 0 & 0 & 0 & \\
\hline Lack of resources & 10.3 & 4 & 5.1 & 2 & & 12.8 & 5 & 0 & 0 & & 0 & 0 & 2.6 & 1 & \\
\hline Chemical agents & 0 & 0 & 0 & 0 & & 0 & 0 & 0 & 0 & & 2.6 & 1 & 2.6 & 1 & \\
\hline Do Not Know & 7.7 & 3 & 2.6 & 1 & & 28.2 & 11 & 23.1 & 9 & & 41 & 16 & 41 & 16 & \\
\hline Total & 100 & 39 & 100 & 39 & & 100 & 39 & 39 & 100 & & 100 & 39 & 100 & 39 & \\
\hline
\end{tabular}

Nota: ${ }^{*} p<0.005,{ }^{* *} p<0.05$

The findings seem to indicate that women with CC may have difficulty perceiving that the locus of control of their disease is external ${ }^{(9)}$. That is, the women with the illness may not realize to what extent the factors related to their lifestyle are associated with the development of the cancer (eg. sexual conduct, physical inactivity, drug use, poor diet, etc.), or the relative insignificance of the self-reported emotional aspects. Conversely, the NCG women attributed more behavioral risk factors to the causes of CC, which are factors that are more easily modified. This type of causal attribution places the women in a pro-active role in preventing the disease, since they can change their behavior, especially in this case, which involves sexual conduct.
It is known that, unlike other cancers, the principal etiological factor of the CC is the presence of the Human Papilloma Virus, which is contagious through sexual intercourse ${ }^{(2)}$. Therefore, sexual risk-taking, such as not using condoms and having multiple partners are behaviors that can be modified. This axpect could be better explored in future studies that evaluate, in addition to causal attributions, possible differences between clinical and non-clinical groups regarding self-care behaviors and lifestyle. This way, it would be possible confirm whether, in fact, there is a distinct behavioral profile when comparing women with and without the disease.

Another aspect that deserves attention is the relationship between family and the causal attribution of the CC. On the 
one hand, the family can be a source of stress (fighting, betrayal) and, as such, may cause suffering for the woman, who feels incapable of changing the situation. On the other hand, the belief that cancer is genetic or from the family also implies an external factor that can not be changed as the cause of the CC, as a women that is powerless to change her supposed genetic profile. However, the environmental role of the lifestyle and the HPV infection involved in the etiology of CC is particular and different when compared to other cancers. Therefore, both causal attributions do not correspond with the reality of the disease and may be important factors in the failure of the woman to prevent it.

These findings corroborate the specific literature on the area that indicates that, in the same way that women with cervical cancer do, women with breast cancer tend to attribute the etiology of the disease to external and uncontrollable factors, such as divine will, destiny, etc. As, this tendency has been established for more than thirty years. Nevertheless, there is a vast amount of scientific evidence that reveals the central role of modifiable risk factors in the control and minimization of the risk for cancer in women ${ }^{(10)}$.

Furthermore, it is important to recognize that, in an isolated manner, causal attributions can not predict and explain the complexity of health behavior. However, knowing the causal attributions to CC helps to understand the beliefs that may influence healthy behavior or not. The beliefs that women keep in regards to the causes of their disease influence their decision to seek help, to adhere to therapeutic procedures and their psychological adjustment during and after treatment ${ }^{(10)}$.

As a cross-sectional study, causal relationships between the variables investigated were not established. The data can not be extrapolated to other populations with different sociodemographic characteristics.
This study involved a carefully paired sample for age and education. This methodological aspect ensures greater confidence in the differences found between groups. Despite this, the results may have been influenced by other variables which are found in aspects not investigated by the researchers (eg. degree of precursor lesion). In this sense, further research can supplement the data found and extend the analysis by including other relevant variables or even more robust designs (ex. longitudinal study).

In conclusion, the data found here provides a basis for reinforcing the need to adjust the perception of women surrounding cancer, especially in regards to the causes of CC. The adjustment of these perceptions can change their thoughts and behaviors when confronting the disease, leading them to a better understanding of their illness and to an active posture towards self-care and treatment. Educational interventions of a preventive nature may be developed to make women aware of the aspects related to CC and adjust the perception of the disease (symptoms, causes, emotional representation, etc.). Such interventions may include a discussion of the difference between the internal and external locus of control. Thus, the causal attributions relating to lifestyle (eg. Physical inactivity, alcohol use, smoking, risky sexual behavior, etc.) may be understood as internal to the individual and therefore changeable. That is, by knowing that she has an active role in self-care, the woman may develop preventive measures to minimize the chances of getting the disease.

\section{REFERENCES}

1. Ferlay J, Soerjomataram I, Ervik M, Dikshit R, Eser S, Mathers C, et al. GLOBOCAN 2012 v1.0: Cancer Incidence and Mortality Worldwide: IARC CancerBase, 
(11), International Agency for Research on Cancer, 2013

2. INCA / Brasil, Ministério da Saúde (2014). Estimativa 2014: Incidência de câncer no Brasil. Rio de Janeiro: INCA

3. Lima EG, Lima DB, Miranda CA, Pereira VS, Azevedo JC, Araújo JG et al. knowledge about hpv and screening of cervical cancer among women from the Metropolitan Region of Natal, Brazil. ISRN Obstet Gynecol 2013: 930479. Doi: 10.1155/2013/930479

4. INCA. Câncer de colo de útero, Brasil, Ministério da Saúde, 2015, disponível em: http://www2 inca.gov.br/wps/wcm/connect/tiposdecancer/site/home/colo_utero

5. Castro EK, Aretz M, Lawrenz P, Romeiro FB \&Haas SA. Illness perceptions in Brazilian women with cervical cancer, women with precursory lesions and healthy women. Psicooncología, 2-3, 417-23. Doi: 10.5209/rev_PSIC.2013.v10.n2-3.43459

6. Huff R, Castro EK. Repercussões Emocionais do Câncer Ginecológico e Exenteração Pélvica. Psicologia e Saúde 2011, 3:33-42.

7. Leventhal $H$, Brissette I, Leventhal EA. The common-sense model of selfregulation of health and illness. In Cameron LD, Leventhal $H$, editors. The self-regulation of health and illness behavior 2003;1:4265.

8. Shiloh S, Rashuk-Rosenthal D, Benyamini Y. Illness Causal Attributions: An exploratory study of their structure and associations with other illness cognitions and perceptions of control. J Behav Med 2002;25:37394. Doi: 10.1023/A:1015818532390

9. Weiner B. An attributional theory of motivation and emotion. Psychol Rev 1986; 92:548-73.

10. Canaria-Dumalao JA, Hutchinson AD, Prichard I, Wilson C. What causes breast cancer? A systematic review of causal attributions among breast cancer survivors and how these compare to expert-endorsed risk factors. Cancer Causes Control
2014:25:771-85. Doi: 10.1007/s10552014-0377-

11. Lizama $N$, Rogers $P$, Thomson A, Slevin T, Fritschi L, Saunders C, Heyworth J. Women's beliefs about breast cancer causation in a breast cancer case-control study. Psychooncology 2015, Doi: 10.1002/ pon.3869

12. Kern de Castro E, Peuker AC, Lawrenz P, Figueiras MJ. Illness Perception, Knowledge and Self-Care about Cervical Cancer. Psicologia Reflexão e Crítica, 2015, 28, 483489. Doi: 10.1590/1678-7153.201528307

13. Thomson AK, Heyworth JS, Girschik J, Slevin T, Saunders C, Fritschi L. Beliefs and perceptions about the causes of breast cancer: A case-control study. BMC Res Notes 2014;7:558. Doi:10.1186/17560500-7-558

14. Figueiras MJ, Machado VA, Alves NC. Os modelos de senso comum das cefaléias crônicas nos casais: relação com o ajustamento marital. Análise Psicológica 2002; 10:177-90.

15. Leventhal H, Nerenz DL, Steele DJ. Illness representation and coping with health threats. In Baum A, Taylor SE, Singer JE, editors. Handbook of Psychology and Health, 1984, 4.p. 219-52.

16. Figueiras MJ, Alves NC. Lay perceptions of serious illnesses: An adapted version of the Revised Illness Perception Questionnaire (IPQ-R) for healthy people. Psychol Health 2007;22:143-58. Doi:10.1080/14768320600774462

17. Weinman J, Petrie K, Moss Morris R, Horne R. The Illness Perception Questionnaire: A new method for assessing the cognitive representation of illness. Psychol Health 1996;11:431-45.

18. Melo SC. Relação entre perceção da tensão arterial elevada e o estilo de vida adotado: estudo exploratório. Dissertação [Mestrado em Psicologia]- Universidade Fernando Pessoa, Porto, Portugal, 2012. 